\title{
History of ethology comes of age
}

\section{Richard W. Burkhardt Jr., Patterns of Behaviour: Konrad Lorenz, Niko Tinbergen and the Founding of Ethology. University of Chicago Press, Chicago, 2005, $636+x i i$ pp., paper back, \$29.00, ISBN-10: 0-226-08090-0}

\section{Paul E. Griffiths}

Received: 9 May 2007/ Accepted: 10 May 2007/Published online: 7 August 2007

(C) Springer Science+Business Media B.V. 2007

The public profile of animal behavior research is out of all proportion to the number of biologists who engage in this kind of work, or the share of funding which they receive. The television genre of the 'wildlife program' was substantially shaped by the early contributions of Niko Tinbergen and his students, such as Desmond Morris at Granada Television. High-profile public controversies about the lessons of animal behavior for society were provoked by Konrad Lorenz's On Aggression (1966), by Morris's The Naked Ape (1967), and more recently by the works of another Tinbergen student, Richard Dawkins. As a result, the popular understanding of Darwinism has been more strongly influenced by ideas from animal behavior research than perhaps any other area of biology. Lorenz's 'hydraulic model' of instinctive behavior was still a hot topic in popular science more than a decade after behavioral biologists abandoned it. Today, the popular understanding of 'genes' owes as much to the abstractions of evolutionary game theory as it does to molecular biology. In the light of its extraordinary impact, it is surprising how little attention animal behavior research has received from historians of science.

In a essay published in 1981, shortly after he began the research which culminated in this book, Buckhardt suggested that the controversy then raging over E.O. Wilson's Sociobiology (1975) and Dawkins' Selfish Gene (1976) should motivate historians to explore the origins of this extraordinary scientific (and social) movement (Burkhardt 1981; see also Durant 1980). For the next 20 years, however, Buckhardt was the only major historian of biology to follow up this compelling suggestion. Some promising researchers left the field (Durant 1981, 1986), and others concentrated their attention on early evolutionary theories of mind and behavior, rather than the flowering of these ideas into a mature scientific discipline after 1945 (Richards 1987). Burkhardt's publications in the

P. E. Griffiths ( $\square)$

The University of Queensland, Brisbane, Australia

e-mail: paul.griffiths@uq.edu.au

Present Address:

P. E. Griffiths

Sydney University, Sydney, Australia 
intervening period have slowly drawn others to the field (e.g., Borello 2003; Brigandt 2005; Griffiths 2004) and the present volume, together with new biographies of Lorenz and Tinbergen far superior to anything available before (Kruuk 2003; Taschwer and Föger 2003), provides the field with the solid foundation it has long needed. Burkhardt's quartercentury of research has culminated in what is perhaps best described as the biography of a discipline. Any student interested in a specific question about animal behavior research in the twentieth century will either find the answer here, or, better still, find the material to contextualize their question and a historiographic framework to guide their interpretations. I will discuss below some of the fascinating questions that can be addressed now that we have these foundations to build upon.

One of Buckhardt's insights is that the 'precursors' to ethology should be seen in their own terms rather than as John the Baptist to ethology's messiah. Much of the knowledge about bird behavior that the founders of ethology drew on was accumulated through the patient observations of naturalists such as Edmund Selous and John Elliott Howard. Burkhardt reveals, for example, how much Julian Huxley's celebrated ethogram of the courtship behavior of the Great Crested Grebe (1914) was in debt to Selous' earlier observations (pp. 116-124). The founders of ethology cited Selous, Howard, Wallace Craig and others as ethologists before their time. However, Selous believed that natural history had been going backwards since Darwin (the title of his Realities of Bird Life (1927) conveys something of his opinion of other workers) and one of his main concerns was to provide evidence for the theory of sexual selection. Hence Selous was at least as much a proto-evolutionary ecologist as a proto-ethologist. This leads us to one of the new questions that can be posed in the light of Burkhardt's foundational research. What was the relationship between ethology and scientific ornithology? In the inter-war years ornithology was a distinct, and distinctly more successful, activity than animal behavior research. As a 'psychological biologist', Lorenz found himself in an institutional no-mans land between zoology and psychology (see esp. pp. 158-160), but his ornithological writings were widely acclaimed and it was to them that most of his early professional successes were due. The British Association for the Study of Animal Behavior struggled unsuccessfully in the 1930s to attract the patronage that would support basic infrastructure such as a field-station or a journal (Durant 1986). In contrast, we are celebrating this year the centenary of the journal British Birds, which even at its inception was something more than a venue for 'popular' or 'amateur' science. As Helen MacDonald has argued, part of the ideology of British ornithology in the inter-war years was to convert birdwatchers into a rigorous, centrally-coordinated scientific instrument of 'mass observation' (MacDonald 2002). The Edward Grey Institute of Field Ornithology at Oxford was already a powerful and established institution when Tinbergen was invited to create a 'research group' on animal behavior in Oxford Zoology Department in 1949. There may be a more direct line to modern behavioral ecology from the work such as that of the Edward Gray Institute Director David Lack's on avian ecology and population biology than there is from Lorenz or Tinbergen's classical studies on 'instinct'.

World War II marks a turning point in Burkhardt's narrative. Before WWII ethologists were often amateurs; after it they rapidly become professionals and ethology became a university-based scientific discipline. About half of Burkhardt's book is devoted to the build up to this critical moment, and about half to its aftermath. It is in the second half of the book that one of Burkhardt's key interpretive ideas comes into its own-the idea of 'scientific ecologies'. Ethology developed differently in different academic settings because ethological research was profoundly influenced by its environments. Colleagues and 
potential collaborators, sources of funding, dominant local standards of scientific rigor, and many other factors shaped a number of different, local 'ethologies'.

One of the clearest examples of the environmental shaping of ethology occurred with Tinbergen and his group at Oxford. The earlier, Lorenzian emphasis on behaviors as taxonomic characters was soon replaced by an emphasis on behaviors as adaptations, a change which reflected the greater role of evolutionary ecology in post-synthesis evolutionary biology in Britain, and particularly in Oxford. As Tinbergen himself noted:

"Being a member of the Oxford setup gave me the unique chance to absorb through daily personal contacts, the typical ecology and evolution study-oriented atmosphere of Oxford zoology. Life in this academic community...influenced my entire outlook, and the group I now began to build up, from very modest beginnings indeed, began to produce work with a distinctly Oxonian flavour.' (Tinbergen 1985: 450-451, see also 1963)

David Lack, the dominant figure in Oxford ornithology at this time, focused on the ecological functions of bird behavior. A similar emphasis was soon apparent in the work of Tinbergen and his students on the comparative behavior of seabirds, most famously in Esther Cullen's ground-breaking studies of the cliff-nesting adaptations of the Kittiwake. Similarities and dissimilarities between species were interpreted in terms of differing selection regimes as well as, and increasingly instead of, taxonomic relationships. In this way Oxford ethology came increasingly to resemble what would later be called 'behavioral ecology'. In fact, in writing the history of animal behavior research in Oxford it would be hard to say at what point the transition from ethology to behavioral ecology occurred. Richard Dawkins, for example, saw his contribution to the sociobiology revolution as a natural continuation of his work with Tinbergen: "My own dominant recollection of [Tinbergen's] undergraduate lectures on animal behaviour was of his ruthlessly mechanistic attitude to animal behaviour and the machinery that underlay it. I was particularly taken with two phrases of his - 'behaviour machinery' and 'equipment for survival'. When I came to write my own first book I combined them into the brief phrase 'survival machine'." (Dawkins et al. 1991: xii).

It is a truism within ethology that the discipline developed in a very different direction at Cambridge. Whilst Dawkins and others practiced 'functional ethology', Robert Hinde, Patrick Bateson and other researchers associated with the Cambridge program created an ethology more focused on behavioral development. Moreover, the difference in research foci was accompanied by different perceptions of what constitutes good science. A wellknown joke had it that the 'Oxford principle' was 'Never use a causal explanation if a teleological one will do instead', whilst the 'Cambridge Principle' was 'Never use a simple explanation if a more complicated one will do instead' (Bateson 2006). The development of ethology at Cambridge was the result of an attempt by the institutionally powerful biologist William H. Thorpe to import classical, Lorenzian research. Thorpe's first idea was to recruit Lorenz himself, taking advantage of the disorganized state of academia in postwar Austria and Germany. This attempt failed when Lorenz was offered support from the Max Planck Society, and in 1950 Robert Hinde was appointed to organize what was initially known as the Ornithological Field Station at Madingley. Although Hinde's doctoral research at Oxford had officially been conducted under David Lack, he was in reality far closer to Tinbergen. The two men remained close, both personally and scientifically, after Hinde moved to Cambridge, but the work of the two research groups rapidly diverged. At some stage in the mid-50s Hinde and Tinbergen explicitly discussed a division of the 'four questions' of ethology (Tinbergen 1963), with the Oxford program focusing on 
'survival value' and 'evolution', and the Cambridge department on 'development' and 'causation' (Hinde, personal communication). Burkhardt's concept of 'scientific ecologies' directs our attention to the contextual factors, which meant that such a discussion was to a large extent a recognition of the facts on the ground. The high value placed on exact experimentation by the Cambridge group may owe something to the work that Thorpe was engaged in as Cambridge ethology took shape. Before the war, Thorpe had carried out laboratory experiments on olfactory conditioning in insects, and in the postwar period he gained access to the only sound-spectrograph in the United Kingdom, a machine until then reserved for secret 'war work', and with Peter Marler pioneered the precise, spectrographic representation of birdsong. But this is only my speculation. Burkhardt has taken us to the point where the story of how Cambridge ethologists came to insist that Behavior is complicated' can be properly elucidated, but that work remains to be done.

Other local ecologies that shaped particular forms of ethology existed in Germanspeaking Europe, and at the American Museum of Natural History. On a larger scale, it is clear that the emergence of ethology after World War II reflected a more global 'ecology' - the post war expansion of higher education and the cold war-driven increase in funding for scientific research. The influence of the Rockerfeller foundation on the history of molecular biology is one of the best-known stories in the history of science, but it was also the Rockerfeller foundation that allowed Thorpe's to acquire his own sound spectrograph at a cost of $\$ 2,700$, a not insignificant sum in 1952 . Thorpe and his colleagues had struggled unsuccessfully in the 1930s to raise similar sums for equally deserving projects. Hence the population of ethologists grew after 1945 because it was no longer constrained by a limiting resource-hard cash. In the same vein, Burkhardt recounts the details of Lorenz's 30 year struggle to obtain an 'official position', a struggle which was one part of the complex story of his embrace of Nazism. In the end, it was the expansion of opportunities in the UK and USA that allowed Lorenz to achieve his aims in Germany. The prospect of a position for Lorenz being created overseas was instrumental in persuading the Max Planck Society to fund his Institute at Budern.

The interaction between Tinbergen and researchers at the American Museum of Natural History predates World War II and, Burckhardt shows, had a substantial impact on the history of ecology. The eclipse of the Lorenzian concept of innateness in Britain is normally attributed to the influence of Theorore C. Schnierla's student at the museum Daniel S. Lehrman. His 1953 critique of Lorenz, closely based on parts of his doctoral dissertation, argued that that endogenous and exogenous influences on behavioral development interact in numerous ways, and that, contra Lorenz, no one pattern of interaction is distinctive of the evolved elements of the behavioral phenotype (Lehrman 1953). Lehrman was also critical of Lorenz's use of the deprivation experiment (raising animals in social isolation and without the ability to practice a behavior) to infer that a behavior is innate simpliciter, rather than merely that the factors controlled for in the experiment are not needed for its development. Both criticisms were closely echoed in Tinbergen's influential 'On the Aims and Methods of Ethology' (Tinbergen 1963). Lehrman had met Tinbergen on his pre-war trip to New York, and their personal relationship was important to the different reception his criticisms received in the UK as compared to German-speaking Europe. The political context of the early cold-war era was also an important contextual factor, as Burkhardt reveals. We should not forget that only a few years earlier, while Lorenz was on the Russian Front and Tinbergen was a German hostage with every prospect of being taken out and shot, Lehrman was intercepting German communications and directing bombing raids into the balkans. 
In his final chapter, Burkhardt describes the rise of E.O. Wilson's 'sociobiology' as a putative replacement for ethology. He notes the irony that Lorenz, Tinbergen and Karl von Frisch, discoverer of bee language, were awarded a joint Nobel Prize in 1973 for their roles in creating a new science of animal behavior just as that science was losing confidence in its own identity. By the early 1970s the population genetic models of William D. Hamilton had created a theoretical tradition that was readily combined with the experimental tradition created by Tinbergen. Behavioral ecologists set out to test the predictions of the new population genetic models through the study of the survival value of different phenotypes in the laboratory and the field. With the rise of 'functional ethology' at Oxford, Tinbergen's 'survival value' and 'evolution' questions had come to be seen as the primary questions in animal behavior research. Hence, whilst the term 'sociobiology' was introduced in a revolutionary manner, the change it denoted had been gradually developing over the previous decade. Wilson's new vision of animal behavior research was unpopular with many ethologists, partly because, as Burckhardt puts it "no one is pleased to hear that others are about to cannibalize his or her field' (p. 462 - 'cannibalize' was Wilson's own term!), and partly because Wilson's vision had no place for the study of behavioral development. The leading birdsong researcher Peter Slater has commented that, "E.O. Wilson...predicted that animal behaviour would be swallowed up by neurobiology at one end and sociobiology at the other. As far as song is concerned he has been largely right but only if, as sociobiologists are prone to do, one ignores development" (Slater 2003). So far as the history of ethology goes, the most important feature of the new behavioral ecology/ sociobiology was the conviction that Tinbergen's four questions are not, as he had himself insisted, closely interlinked. During the 1960s different ethological researchers had come to focus on different parts of the Tinbergian research program. Ethology as a discipline ceased to exist when these researchers ceased to see themselves as tackling different aspects of the same problem.

This brings us back to the question that Burkhardt raised in 1981, and with which I began this essay, of the historical origins of sociobiology. Once again, Burkharts' conception of a 'scientific ecology' is helpful. I have argued elsewhere that behavioral ecology/sociobiology, with its study of adaptive value and evolutionary origins, had a 'selective advantage' over the study of causation and ontogeny during the 1970s (Griffiths, In Press). No new discipline comparable to behavioral ecology arose from the other parts of Tinbergen's program, and the rising generation of animal behavior researchers was predominantly attracted to behavioral ecology. Two things may help to explain this. First, behavioral ecology made it possible to see particular studies as tests of general hypotheses about the evolutionary process. It possessed game theoretic and population genetic models of a very high degree of generality, and a single, practicable study in the field or the laboratory could constitute a test of the predictions of an entire class of models, such as optimal foraging theory or parental investment theory. With the possible exception of the template theory of song acquisition in passerine birds, the study of causation and behavioral development did not offer general theories of a kind whose adequacy could be meaningfully tested in a single series of experiments. It is not difficult to see why a field in which a practicable series of experiments could test an important theory would be more appealing to young researchers than a field in which in which this appeared impossible.

Second, the study of behavioral causation and ontogeny was simply not able to keep up with the study of adaptive value, forcing pragmatic researchers to look for ways to make their research independent of answers to such apparently intractable questions. Studies of causation and ontogeny could, in principle, have contributed to behavioral ecology in a very direct way, by determining a realistic 'phenotype set' available for selection to act 
upon, but in almost all cases those studies were not advanced enough to provide this information. In practice, the phenotype sets of evolutionary models were based on what actually occurs in nature, or on what seemed biologically plausible to the researchers. Hence, instead of developmental biology making a positive contribution to behavioral ecology, it appeared only in the negative role of 'developmental constraints' - sets of phenotypes that were supposed on indirect evidence to be for some unknown reason, impossible to construct.

There is more to be written on the history animal behavior research, the story of Lehrman's Institute for the Study of Animal Behavior at Rutgers and its relationship to the American left during the cold war, to take one particularly urgent example, but whatever is written will undoubtedly take Patterns of Behavior as its starting point.

\section{References}

Bateson PPG (2006) The nest's tale: a reply to Richard Dawkins. Biol Philos 21(4):553-558

Borello M (2003) Synthesis and selection: Wynne-Edwards' challenge to David Lack. J Hist Biol 36(3):531-566

Brigandt I (2005) The instinct concept of the early Konrad Lorenz. J Hist Biol 38:571-608

Burkhardt RW Jr (1981) On the emergence of ethology as a scientific discipline. Conspectus Hist 1(7):62-81

Dawkins MS, Halliday TR, Dawkins R (eds) (1991) The Tinbergen legacy. Chapman and Hall, London

Dawkins R (1976) The selfish gene. Oxford University Press, Oxford

Durant JR (1980) Exploring the roots of sociobiology. Br J Hist Sci 13(March):55-60

Durant JR (1981) Innate character in animal and man: a perspective on the origins of ethology. In: C Webster (ed) Biology, medicine and society 1840-1940. Cambridge University Press, Cambridge pp $157-192$

Durant JR (1986) The making of ethology: the association for the study of animal behaviour, 1936-1986. Anim Behav 34:1601-1616

Griffiths PE (2004) Instinct in the '50s: the British reception of Konrad Lorenz's theory of instinctive behaviour. Biol Philos 19(4):609-631

Griffiths PE (In Press) Ethology, sociobiology and evolutionary psychology. In: S Sarkar, A Plutyinski (eds), Blackwell's Companion to Philosophy of Biology Blackwells, Oxford

Huxley J (1914) The courtship-habits of the great crested grebe (Podiceps cristatus); with an addition to the theory of sexual selection. Proc Zool Soc Lond 35:491-562

Kruuk H (2003) Niko's nature: the life of Niko Tinbergen and his science of animal behavior. Oxford University Press, Oxford

Lehrman DS (1953) Critique of Konrad Lorenz's theory of instinctive behavior. Q Rev Biol 28(4):337-363

Lorenz KZ (1966) On Aggression (MK Wilson, Trans). Harcourt, Brace and World, New York

MacDonald H (2002) 'What makes you a scientist is the way you look at things': ornithology and the observer, 1933-1955. Stud His Philos Biol Biomed Sci 33C(1):53-78

Morris D (1967) The naked ape: a zoologist's study of the human animal. Cape, London

Richards RJ (1987) Darwin and the emergence of evolutionary theories of mind and behavior. Univ of Chicago Press, Chicago

Selous E (1927) Realities of bird life: being extracts from the diaries of a life-loving naturalist. Constable, London

Slater PJB (2003) Fifty years of bird song research: a case study in animal behaviour. Anim Behav 65:633639

Taschwer K, Föger B (2003) Konrad Lorenz. Zsolnay, Wien

Tinbergen N (1963) On the aims and methods of ethology. Z Tierpsychol 20:410-433

Tinbergen N (1963) The work of the animal behaviour research group in the department of zoology, University of Oxford. Anim Behav 11:206-209

Tinbergen N (1985) Watching and wondering. In: DA Dewsbury (ed) Leaders in the Study of animal behavior: autobiographical perspectives. Associated University Presses, London and Toronto, pp 431463

Wilson EO (1975) Sociobiology: the new synthesis. Harvard University Press, Cambridge, MA 